\title{
Do Mated Tribolium confusum Adults Respond to Blends of Odors?
}

\author{
Anna Wenda-Piesik¹, Dariusz Piesik ${ }^{2 *}$, Bogusław Buszewski ${ }^{3}$ \\ ${ }^{1}$ UTP University of Science and Technology, Department of Plant Growth Principles and Experimental Methodology, \\ 85-225 Bydgoszcz, 20 Kordeckiego St., Poland \\ ${ }^{2}$ UTP University of Science and Technology, Department of Entomology and Molecular Phytopathology, \\ 85-225 Bydgoszcz, 20 Kordeckiego St., Poland \\ ${ }^{3}$ Nicolaus Copernicus University, Faculty of Chemistry, Chair of Environmental Chemistry and Bioanalytics, \\ 87-100 Toruń, 7 Gagarina St., Poland
}

Received: 11 April 2016

Accepted: 19 July 2016

\begin{abstract}
In this paper we report the behavioral responses of mated Tribolium confusum to blends of volatiles using a Y-tube olfactometer. Four doses of volatiles $\left(1 \mathrm{ng} \cdot \mathrm{min}^{-1}, 10 \mathrm{ng} \cdot \mathrm{min}^{-1}, 100 \mathrm{ng} \cdot \mathrm{min}^{-1}\right.$, and 1,000 ng min ${ }^{-1}$ in $50 \mu$ of hexane applied on filter paper) were tested. A Y-tube experiment revealed that both mated females and males of Tribolium confusum were attracted to blends 4 and 5 at concentrations of $100 \mathrm{ng} \cdot \mathrm{min}^{-1}$ and $10 \mathrm{ng} \cdot \mathrm{min}^{-1}$, respectively. Moreover, mated females of tested insects were also attracted to blends 1 and 5 . Yet the weevil females and males were repelled by the highest concentrations $\left(1,000 \mathrm{ng} \cdot \mathrm{min}^{-1}\right)$ for all tested blends. Additionally, a $100 \mathrm{ng} \cdot \mathrm{min}^{-1}$ concentration also repelled both sexes in blends 2, 3, 5, and 6 .
\end{abstract}

Keywords: Tribolium confusum, confused flour beetle, cereal volatiles, attractants, repellents

\section{Introduction}

Stored product pests can cause direct losses in product weight. They can affect stock, damage products by reducing their weight, or contaminate them [1]. Large quantities of these crops (during storage) - accounting for $5-10 \%$ in temperate and $20-30 \%$ or more in tropical regions - are lost annually due to different insect pests [2]. As calculated by Grethe et al. [3], an increase of $48 \%$ in food production would be sufficient when post-harvest losses are seriously reduced [4].

Tribolium confusum Jacquelin du Val (Coleoptera: Tenebrionidae) is one of the major foodstuff pests

*e-mail: piesik@utp.edu.pl responsible for important economic losses and is still central to the world food supply since cereals continue to be the main source of food for people [56]. The confused flour beetle is a cosmopolitan pest of stored grains, cereal products, fruit, and nut products, and they may infest mills, food warehouses, or retail stores. Moreover, they can contaminate processing plants and warehouses by whole insects, eggs, insect fragments, and frass [7].

For years, chemical treatment with insecticides has been the method of choice. However, the number of available active substances has been shrinking due to many reasons [8-9]. Pest management programs for stored-product insects inside mills and warehouses may include applications with insecticides of different liquid formulations, including aerosols [10]. Therefore, aerosol 
insecticide applications are predicted to cause direct mortality only to individuals dispersing between refugia and out in open areas because they can either be directly exposed to settling droplets or encounter the residual insecticide on treated surfaces [11]. The control of these insects relies heavily on the use of cost-effective synthetic insecticides such as fumigants (mainly phosphine and methyl bromide) [12], but their massive use has triggered problems such as resistant behavior and environmental pollution with negative side effects on human health [13-15]. Possible strategies aimed at reducing the use of synthetic insecticides include natural insecticide fumigants produced by plants [16].

Eco-friendly strategies to prevent such insect attacks on final packaged products are therefore highly required, e.g., essential oils (extracted from aromatic plants) could represent an alternative to chemical treatments due to their repellent properties [17-21].

Plants are vulnerable to attack by organisms, but even being immobile are not merely passive victims [22]. To protect themselves, they have evolved an arsenal of physical and chemical defences [23-25], e.g., there are many types of volatile organic compounds (VOCs) released by plants in response to insect attack (terpenes, fatty acid derivatives, benzenoids, phenyl propanoids, and amino acid-derived metabolites) [26]. Plant-induced VOC defensive functions include directly deterring herbivores [27-28], indirectly attracting natural enemies of attackers [29], and priming defences of uninjured organs on the same plant [30-32]. An insect dose response to an individual plant VOC can reveal the range of concentrations over which herbivore or parasitoid attraction or repellence occurs [33-34].

In the present study, we examined the behavioral response of mated adults of $T$. confusum of both sexes to blends of VOCs.

\section{Experimental Procedures}

Insects

Experiments were performed in 2014-15 at the UTP University of Science and Technology, Bydgoszcz, Poland at the Department of Entomology and Molecular Phytopathology. T. confusum were reared on whole wheat kernels in continuous dark at $22 \pm 2^{\circ} \mathrm{C}$ and relative humidity of $60 \pm 5 \%$.

\section{Synthetic Chemicals}

Synthetic volatiles were obtained from Sigma-Aldrich (Chemical Co. Inc., Poznan, Poland) and their purity was $85-99 \%$. Cereal compounds were selected based on their presence in cereal grains [35], but plant VOCs were chosen based on their presence in various cereal green plants as a result of biotic stress [36-38]. To screen behavioral activity of the volatile compounds we tested six blends at four concentrations $(1,10,100$,
1,000 ng.min-197) compared to the absence of the compound $(0)$. In the Y-tube, each of the five VOC concentrations in hexane was tested against hexane solvent alone. Each of the 98 individual VOCs was present in a blend at the specified concentration. Thus for blend 1 (aliphatic alcohols), $1 \mathrm{ng} \cdot \mathrm{min}^{-1}$ means that $1 \mathrm{ng} 1$-BUT $+1 \mathrm{ng} 1$-PEN $+1 \mathrm{ng} 1$-HEX $+1 \mathrm{ng} 3$-MET was added to $50 \mu \mathrm{l}$ hexane. A dose of a blend was placed in one arm of the Y-tube and tested against $50 \mu \mathrm{l}$ hexane without the blend $\left(0 \mathrm{ng} \cdot \mathrm{min}^{-1}\right)$.

\section{Y-tube}

Insects of both sexes were exposed to each other for $72 \mathrm{~h}$ in a cage where food was also supplied. After three days they were separated (different cages) and following another $24 \mathrm{~h}$ the experiment were begun. Beetles tended to walk along the Y-tube (this system has been previously tested on various insect species) [21]. Twenty adult $T$. confusum of each sex were tested (20오 and $20 \hat{0}$ for each blend) at each concentration for six blended VOCs. Adults were observed for $5 \mathrm{~min}$.

\section{Data Analysis}

Chi-square goodness of fit tests (X2-test) with the Yates correction for small samples $(1 \times 2)$ were conducted to indicate whether the choice of Y-tube arms was influenced by a preference for odor source (synthetic blend vs. hexane solvent) at each exposure concentration $\times \operatorname{sex} \times$ exposure duration combination. Non-significant tests indicated that the observed beetle counts did not significantly deviate from an expected ratio of 10:10 (the hexane solvent only arm and synthetic blend). Significant tests indicated attraction (more individuals chose The Y-tube arm with a synthetic blend) or repellency (more individuals chose the Y-tube arm with only hexane solvent).

\section{Discussion of Results}

We found in our behavioral responses of mated confused flour beetles that mated females of $T$. confusum were attracted to blends 1,4 , and 5 at concentrations of $100 \mathrm{ng} \cdot \mathrm{min}^{-1}, 100 \mathrm{ng} \cdot \mathrm{min}^{-1}, 1$ and $10 \mathrm{ng} \cdot \mathrm{min}^{-1}$, respectively (Tables 1, 4, 5). In contrast, mated males were attracted only to blend 5 at a concentration of $10 \mathrm{ng} \mathrm{min}^{-1}$. Both sexes were repelled by the highest concentration $(1,000$ $\mathrm{ng} \cdot \mathrm{min}^{-1}$ ) for all tested blends. Additionally, both mated sexes were repelled by $100 \mathrm{ng} \cdot \mathrm{min}^{-1}$ in blends $2,3,5$, and 6 (Tables 2, 3, 5, 6). .

The above results are in good agreement with those of Zoubiri and Baaliouamer [39], who tested the bioactivity of the essential oil extracted by hydrodistillation from Lantana camara leaves and found that the composition of $L$. camara essential oil included large amounts of sesquiterpene - mainly $\beta$-caryophyllene and caryophyllene oxide. Ziaee et al. [40] found that essential oil had strong fumigant toxicity against adult insects; however, toxicity diminished in the presence of wheat commodity. Plant 
Table 1. Effect of synthetic blend No. 1 of four aliphatic alcohols [1-BUT +1 -PEN +1 -HEX +3 -MET] on the number of mated Tribolium confusum adult females and males choosing to enter a Y-tube arm containing the blend odor or the Y-tube arm containing purified humidified air and hexane solvent (no odor).

\begin{tabular}{|c|c|c|c|c|c|c|c|c|}
\hline \multirow{2}{*}{$\begin{array}{c}\text { Name of mixed } \\
\text { compounds }\end{array}$} & \multirow{2}{*}{ Dose } & \multirow{2}{*}{ ng.min } & \multicolumn{3}{|c|}{ No. of females } & \multicolumn{4}{c|}{ No. of males } \\
\cline { 4 - 9 } & & & $+{ }^{4}$ & $-{ }^{5}$ & $\chi^{2(1)}$ & $+{ }^{4}$ & $-^{5}$ & $\chi^{2(1)}$ \\
\hline Control & 0.0 & 7 & 13 & $1.25 \mathrm{~ns}$ & 11 & 9 & $0.05 \mathrm{~ns}$ \\
\hline+ 1-BUT & 1 & 1 & 8 & 12 & $0.45 \mathrm{~ns}$ & 10 & 10 & $0.05 \mathrm{~ns}$ \\
\hline+ 1-PEN & 2 & 10 & 9 & 11 & $0.05 \mathrm{~ns}$ & 13 & 7 & $1.25 \mathrm{~ns}$ \\
\hline+ 1-HEX & 3 & 100 & 16 & 4 & $6.05^{*}(\mathrm{a})^{3}$ & 14 & 6 & $2.45 \mathrm{~ns}$ \\
\hline$+3-\mathrm{MET}$ & 4 & 1000 & 3 & 17 & $8.45^{* *}(\mathrm{r})^{2}$ & 4 & 16 & $6.05^{*}(\mathrm{r})^{2}$ \\
\hline
\end{tabular}

Legend:

(1) level of significance (ns: non-significant), $\left({ }^{*} \mathrm{p}<0.05\right),\left({ }^{* *} \mathrm{p}<0.01\right),(* * * \mathrm{p}<0.001)$

${ }^{2}$ r: repellent

${ }^{3}$ a: attractant

${ }^{4}+$ Y: tube arm with the tested amount of the compound, volatile diluted in hexane emitted from filter paper

5 - Y: tube arm only with hexane emitted from filter paper

Table 2. Effect of synthetic blend No. 2 of eight aliphatic aldehydes [BUT + PEN + HEX + HEP $+(E)-2$-HEX $+(E, E)-2,4-H E P+$ $(E, E)-2,4-\mathrm{NON}+(E, E)-2,4-\mathrm{DEC}]$ on the number of mated Tribolium confusum adult females and males choosing to enter a Y-tube arm containing the blend odor or the Y-tube arm containing purified humidified air and hexane solvent (no odor).

\begin{tabular}{|c|c|c|c|c|c|c|c|c|}
\hline \multirow{2}{*}{$\begin{array}{c}\text { Name of mixed } \\
\text { compounds }\end{array}$} & \multirow{2}{*}{ Dose } & \multirow{2}{*}{$\mathrm{ng} \mathrm{min}^{-1}$} & \multicolumn{3}{|c|}{ No. of females } & \multicolumn{3}{|c|}{ No. of males } \\
\cline { 4 - 9 } & & +4 & -5 & $\chi^{2(1)}$ & +4 & -5 & $\chi^{2(1)}$ \\
\hline $\begin{array}{c}\text { BUT } \\
+ \text { PEN }\end{array}$ & Control & 0.0 & 10 & 10 & $0.05 \mathrm{~ns}$ & 13 & 7 & $1.25 \mathrm{~ns}$ \\
\hline+ HEX & 1 & 1 & 11 & 9 & $0.05 \mathrm{~ns}$ & 8 & 12 & $0.45 \mathrm{~ns}$ \\
\hline+ HEP & 2 & 10 & 14 & 6 & $2.45 \mathrm{~ns}$ & 11 & 9 & $0.05 \mathrm{~ns}$ \\
\hline$+(E)-2-\mathrm{HEX}$ & 3 & 100 & 4 & 16 & $6.05^{*}(\mathrm{r})^{2}$ & 4 & 16 & $6.05 *(\mathrm{r})^{2}$ \\
\hline $\begin{array}{c}+(E, E)-2,4-\mathrm{HEP} \\
+(E, E)-2,4-\mathrm{NON} \\
+E, E)-2,4-\mathrm{DEC}\end{array}$ & 4 & 1000 & 2 & 18 & $11.3^{* * *}(\mathrm{r})^{2}$ & 3 & 17 & $8.45^{* *}(\mathrm{r})^{2}$ \\
\hline
\end{tabular}

Table 3. Effect of synthetic blend No. 3 of four aliphatic ketones [2-PEN + 2-HEX + 2-HEP + 2,3-BUT] on the number of mated Tribolium confusum adult females and males choosing to enter a Y-tube arm containing the blend odor or the Y-tube arm containing purified humidified air and hexane solvent (no odor).

\begin{tabular}{|c|c|c|c|c|c|c|c|c|}
\hline \multirow{2}{*}{$\begin{array}{l}\text { Name of mixed } \\
\text { compounds }\end{array}$} & \multirow{2}{*}{ Dose } & \multirow{2}{*}{ ng. $\min ^{-1}$} & \multicolumn{3}{|c|}{ No. of females } & \multicolumn{3}{|c|}{ No. of males } \\
\hline & & & $+{ }^{4}$ & $-{ }^{5}$ & $\chi^{2(1)}$ & $+{ }^{4}$ & $-{ }^{5}$ & $\chi^{2(1)}$ \\
\hline & Control & 0.0 & 14 & 6 & $2.45 \mathrm{~ns}$ & 13 & 7 & $1.25 \mathrm{~ns}$ \\
\hline 2-PEN & 1 & 1 & 9 & 11 & $0.05 \mathrm{~ns}$ & 7 & 13 & $1.25 \mathrm{~ns}$ \\
\hline$+2-\mathrm{HEX}$ & 2 & 10 & 11 & 9 & $0.05 \mathrm{~ns}$ & 11 & 9 & $0.05 \mathrm{~ns}$ \\
\hline + 2-HEP & 3 & 100 & 3 & 17 & $8.45^{* *}(\mathrm{r})^{2}$ & 5 & 15 & $4.05 *(r)^{2}$ \\
\hline +2,3-BUT & 4 & 1000 & 3 & 17 & $8.45^{* *}(\mathrm{r})^{2}$ & 4 & 16 & $6.05^{*}(\mathrm{r})^{2}$ \\
\hline
\end{tabular}

essential oil synergized the performance of diatomaceous earth (DE) samples such that they generally became more insecticidal than DE alone. Nenaah [2] found that essential oils of Achillea biebersteinii, A. santolina, and A. mellifolium showed considerable toxic and growth inhibitory activities against the red flour beetle, Tribolium castaneum (Herbst). Germinara et al. [35] demonstrated that at the end of the aging period, the percentage of $S$. granarius adults found in cartons coated with propionic acid-loaded mono and multilayer PCL and zein was only $13.1 \%, 11.3 \%, 18.0 \%$, and $10.7 \%$ of the total number of insects used in the bioassay, respectively. Piesik et al. 
Table 4. Effect of synthetic blend No. 4 of four aromatics [MAL, FUR, PHE, VAN] on the number of mated Tribolium confusum adult females and males choosing to enter a Y-tube arm containing the blend odor or the Y-tube arm containing purified humidified air and hexane solvent (no odor).

\begin{tabular}{|c|c|c|c|c|c|c|c|c|}
\hline \multirow{2}{*}{$\begin{array}{c}\text { Name of mixed } \\
\text { compounds }\end{array}$} & \multirow{2}{*}{ Dose } & \multirow{2}{*}{ ng $\mathrm{min}^{-1}$} & \multicolumn{3}{|c|}{ No. of females } & \multicolumn{4}{|c|}{ No. of males } \\
\cline { 4 - 9 } & & & +4 & -5 & $\chi^{2(1)}$ & $+{ }^{4}$ & $-^{5}$ & $\chi^{2(1)}$ \\
\hline Control & 0.0 & 8 & 12 & $0.45 \mathrm{~ns}$ & 10 & 10 & $0.05 \mathrm{~ns}$ \\
\hline MAL & 1 & 1 & 12 & 8 & $0.45 \mathrm{~ns}$ & 10 & 10 & $0.05 \mathrm{~ns}$ \\
\hline+ FUR & 2 & 10 & 7 & 13 & $1.25 \mathrm{~ns}$ & 13 & 7 & $1.25 \mathrm{~ns}$ \\
\hline+ PHE & 3 & 100 & 16 & 4 & $6.05 *(\mathrm{a})^{3}$ & 15 & 5 & $4.05 *(\mathrm{r})^{2}$ \\
\hline+ VAN & 4 & 1000 & 2 & 18 & $11.3^{* * *(\mathrm{r})^{2}}$ & 3 & 17 & $8.45^{* *}(\mathrm{r})^{2}$ \\
\hline
\end{tabular}

Table 5. Effect of synthetic blend No. 5 of aliphatic alcohols, aliphatic aldehydes, aliphatic ketones, and aromatics on the number of mated Tribolium confusum adult females and males choosing to enter a Y-tube arm containing the blend odor or the Y-tube arm containing purified humidified air and hexane solvent (no odor).

\begin{tabular}{|c|c|c|c|c|c|c|c|c|}
\hline \multirow{2}{*}{$\begin{array}{l}\text { Name of mixed } \\
\text { compounds }\end{array}$} & \multirow[b]{2}{*}{ Dose } & \multirow[b]{2}{*}{$\mathrm{ng} \cdot \mathrm{min}^{-1}$} & \multicolumn{3}{|c|}{ No. of females } & \multicolumn{3}{|c|}{ No. of males } \\
\hline & & & +4 & -5 & $\chi^{2(1)}$ & $+{ }^{4}$ & -5 & $\chi^{2(1)}$ \\
\hline & Control & 0.0 & 7 & 13 & $1.25 \mathrm{~ns}$ & 11 & 9 & $0.05 \mathrm{~ns}$ \\
\hline aliphatic alcohols & 1 & 1 & 16 & 4 & $6.05 *(a)^{3}$ & 10 & 10 & $0.05 \mathrm{~ns}$ \\
\hline+ aliphatic aldehydes & 2 & 10 & 16 & 4 & $6.05 *(a)^{3}$ & 16 & 4 & $6.05 *(a)^{3}$ \\
\hline+ aliphatic ketones & 3 & 100 & 3 & 17 & $8.45 * *(r)^{2}$ & 5 & 15 & $4.05 *(r)^{2}$ \\
\hline+ aromatics & 4 & 1000 & 2 & 18 & $11.3^{* * *}(\mathrm{r})^{2}$ & 3 & 17 & $8.45 * *(r)^{2}$ \\
\hline
\end{tabular}

Table 6. Effect of synthetic blend No. 6 of six plant VOCs [(Z)-OCI, LIN, BAC, MAT, $\boldsymbol{\beta}$-CAR, (E)- $\boldsymbol{\beta}$-FAR] on the number of mated Tribolium confusum adult females and males choosing to enter a Y-tube arm containing the blend odor or the Y-tube arm containing purified humidified air and hexane solvent (no odor).

\begin{tabular}{|c|c|c|c|c|c|c|c|c|}
\hline \multirow{2}{*}{$\begin{array}{c}\text { Name of mixed } \\
\text { compounds }\end{array}$} & \multirow{2}{*}{ Dose } & \multirow{2}{*}{ ng $\mathrm{min}^{-1}$} & \multicolumn{3}{|c|}{ No. of females } & \multicolumn{4}{|c|}{ No. of males } \\
\cline { 4 - 9 } & & $+{ }^{4}$ & $-{ }^{5}$ & $\chi^{2(1)}$ & $+{ }^{4}$ & $-^{5}$ & $\chi^{2(1)}$ \\
\hline (Z)-OCI & Control & 0.0 & 10 & 10 & $0.05 \mathrm{~ns}$ & 12 & 8 & $0.05 \mathrm{~ns}$ \\
\hline+ LIN & 1 & 1 & 8 & 12 & $0.45 \mathrm{~ns}$ & 14 & 6 & $2.45 \mathrm{~ns}$ \\
\hline+ BAC & 2 & 10 & 7 & 13 & $1.25 \mathrm{~ns}$ & 10 & 10 & $0.05 \mathrm{~ns}$ \\
\hline+ MAT & 3 & 100 & 2 & 18 & $11.3^{* * *}(\mathrm{r})$ & 4 & 16 & $6.05 *(\mathrm{r})^{2}$ \\
\hline$+\beta$-CAR & 4 & 1000 & 2 & 18 & $11.3^{* * *(\mathrm{r})^{2}}$ & 3 & 17 & $8.45^{* *}(\mathrm{r})^{2}$ \\
\hline
\end{tabular}

Legend:

(1) level of significance (ns: non-significant), $\left({ }^{*} \mathrm{p}<0.05\right),\left({ }^{* *} \mathrm{p}<0.01\right),\left({ }^{* * *} \mathrm{p}<0.001\right)$

${ }^{2}$ r: repellent

${ }^{3}$ a: attractant

${ }^{4}+$ Y: tube arm with the tested amount of the compound, volatile diluted in hexane emitted from filter paper

5 - Y: tube arm only with hexane emitted from filter paper

[41] found attraction to synthetic components for adult cereal leaf beetles Oulema melanopus L. (Coleoptera: Chrysomelidae) at 7,500 $\mathrm{ng} \cdot \mathrm{h}^{-1}$ for two GLVs ((Z)-3hexenal, (Z)-3-hexen-1-yl acetate) and two terpenes (linalool and $\beta$-caryophyllene), and attraction at lower doses of $60 \mathrm{ng} \cdot \mathrm{h}^{-1}$ for ((Z)-3-hexenal, (Z)-3-hexen-1-yl acetate, and $300 \mathrm{ng} \cdot \mathrm{h}^{-1}$ for linalool.

\section{Chemical Compounds and Abbreviation List}

VOCs $=$ volatile organic compounds; blend 1 - aliphatic alcohols $(1-$ Butanol $=1$-BUT, 1-Pentanol $=1$-PEN, 1-Hexanol =1-HEX, 3-Methyl-1-butanol=3-MET); blend 2 - aliphatic aldehydes $($ Butanal $=$ BUT, Pentanal $=$ PEN, 
Hexanal $=$ HEX, Heptanal $=$ HEP, $(E)-2-$ Hexenal $=(E)-2-$ $\operatorname{HEX},(E, E)-2,4-H e p t a d i e n a l=(E, E)-2,4-H E P,(E, E)-2,4-$ Nonadienal $=(E, E)-2,4-\mathrm{NON},(E, E)-2,4$-Decadienal $=$ $(E, E)-2,4-\mathrm{DEC})$; blend 3 - aliphatic ketones (2- Pentanone $=2$-PEN, 2-Hexanone $=2$-HEX, 2-Heptanone = 2-HEP, 2,3-Butanedione $=2,3$-BUT); blend 4 - aromatics (3-Methoxy-2-methyl-4-pyrone (maltol) $=$ MAL, 132 Furfural = FUR, Phenylacetaldehyde = PHE, 3-Methoxy-4-hydroxybenzaldehyde $($ vanillin $)=$ VAN); blend 5 - aliphatic alcohols, aliphatic aldehydes, aliphatic ketones, aromatics, blend 6 - plant VOCs $((\mathrm{Z})$-ocimene $=(\mathrm{Z})$-OCI, linalool $=\mathrm{LIN}$, benzyl acetate $=\mathrm{BAC}$, methyl salicylate $=$ MAT, $\beta$-caryophyllene $=\beta$-CAR, $(E)-\beta$-farnesene $=(E)-\beta-F A R)$.

\section{Acknowledgements}

The authors thank Magdalena Piesik (Nicolaus Copernicus University, Ludwik Rydygier Collegium Medicum in Bydgoszcz, Poland) for her invaluable assistance with experimental work. The experiments were done in the laboratory of the Regional Center for Innovation (RCI) at the University of Science and Technology in Bydgoszcz.

\section{References}

1. BELDA C., RIUDAVETS J. Attraction of the parasitoid Anisopteromalus calandrae (Howard) (Hymenoptera: Pteromalidae) to odors from grain and stored product pests in a Y-tube olfactometer. Biol. Control 54, 29, 2010.

2. NENAAH G.E. Chemical composition, toxicity and growth inhibitory activities of essential oils of three Achillea species and their nano-emulsions against Tribolium castaneum (Herbst). Ind. Crops Prod. 53, 252, 2014.

3. GRETHE H., DEMBÉLÉ A., DUMAN N. How to Feed the World's Growing Billions-Understanding FAO World Food Projections and Their Implications. WWF and HeinrichBoll-Stiftung, Berlin, 2011.

4. NIEDERMAYER S., STEIDLE J. L. M. The Hohenheimer Box - A new way to rear and release Lariophagus distinguendus to control stored product pest insects. Biol. Control 64, 263, 2013.

5. ALONSO-AMELOT M., AVILA-NÚŇEZ J. Comparison of seven methods for stored cereal losses to insects for their application in rural conditions. J. Stored Prod. Res. 47, 82, 2011.

6. GOLESTAN M. N., GHOStA Y., POURMirZA A. A., VALIZADEGAN O. Study on laser perforated films as gas permeable packaging for confused flour beetle (Tribolium confusum Jacquelin du Val.) control inside food packaging. J. Stored Prod. Res. 60, 54, 2015.

7. SUTTON A. E., ARTHUR F. H., ZHU K. Y., CAMPBELL J. F., MURRAY L. W. Residual efficacy of synergized pyrethrin + methoprene aerosol against larvae of Tribolium castaneum and Tribolium confusum (Coleoptera: Tenebrionidae). J. Stored Prod. Res. 47, 399, 2011.

8. CLARKE J. H., WYNN S. C., TWINING S. E. Impact of changing pesticide availability. Aspects Appl. Biol. 106, 263, 2011.

9. OPIT G. P., PHILIPPS T. W., AIKINS M. J., HASAN M. M. Phosphine Resistance in Tribolium castaneum and
Rhzopertha dominica from Stored Wheat in Oklahoma. J. Econ. Entomol. 105, 1107, 2012.

10. ARTHUR F.H. Residual efficacy of pyrethrin + methoprene for control of Tribolium castaneum and Tribolium confusum in a commercial flour mill. J. Stored Prod. Res. 64, 42, 2015.

11. TUCKER A.M., CAMPBELL J.F., ARTHUR F.H., ZHU K.Y. Horizontal transfer of methoprene by Tribolium castaneum (Herbst) and Tribolium confusum Jacquelin du Val. J. Stored Prod. Res. 57, 7, 2014.

12. ISLAM M.S., HASAN M.M., LEI C., MUCHA-PELZER T., MEWIS I., ULRICHS C. Direct and admixture toxicity of diatomaceous earth and monoterpenoids against the storage pests Callosobruchus maculates (F.) and Sitophilus oryzae (L.). J. Pest Sci. 83, 105, 2010.

13. ALI A., AHMAD F., BIONDI A., WANG Y., DESNEUX N. Potential for using Datura alba leaf extracts against two major stored grain pests, the khapra beetle Trogoderma granarium and the rice weevil Sitophillus oryzae. J. Pest Sci. 85, 359, 2012.

14. SKEVAS T., SWINTON S.M., MEEHAN T.D., KIM T.N., GRATTON C., EGBENDEWE-MONDZOZO A. Integrating agricultural pest biocontrol into forecasts of energy biomass production. Ecol. Econ. 106, 195, 2014.

15. WERDIN GONZÁLEZ J.O., LAUMANN R.A., DA SILVEIRA S., MORAES M.C.B., BORGES M., FERRERO A. A. Lethal and sublethal effects of four essential oils on the egg parasitoids Trissolcus basalis. Chemosphere 92, 608, 2013.

16. MANSOUR E.E., MI F., ZHANG G., JIUGAO X., WANG Y., KARGBO A. Effect of allylisothiocyanate on Sitophilus oryzae, Tribolium confusum and Plodia interpunctella: Toxicity and effect on insect mitochondria. Crop Prot. 33, 40, 2012.

17. BOCZEK J., KIEŁKIEWICZ M., KACZMARCZYK A. Herbivore-induced plant volatiles and their potential role in integrated pest management [Lotne związi emitowane $\mathrm{z}$ roślin zasiedlonych przez fitofagi i ich znaczenie w integrowanej ochronie]. Progr. Plant Prot./Post. Ochr. Roślin 53, 661, 2013 [In Polish].

18. BOUGHERRA H.H., BEDINI S., FLAMINI G., COSCI F., BELHAMEL K., CONTI B. Pistacia lentiscus essential oil has repellent effect against three majorinsect pests of pasta. Ind. Crops Prod. 63, 249, 2015.

19. GANTNER M., NAJDA A. Essential oils from buds and leaves of two hazelnut (Corylus L.) cultivars with different resistance to filbert big bud mite (Phytoptus avellanae Nal.) and filbert aphid (Myzocallis coryli Goetze). ArthropodPlant Inte. 7, 659, 2013.

20. QAWASMEH A., RAMAN A., WHEATLEY W. Volatiles in perennial ryegrass infected with strains of endophytic fungus: impact on African black beetle host selection. J. Appl. Entomol. 139, 94, 2015.

21. PIESIK D., KALKA I., WENDA-PIESIK A., BOCIANOWSKI J. Apion miniatum Germ. herbivory on the mossy sorrel, Rumex confertus Willd.: Induced plant volatiles and weevil orientation responses. Polish J. Environ. Stud. 23, 2149, 2014.

22. DICKE M., VAN LOOP J.J.A., SOLER R. Chemical complexity of volatiles from plants induced by multiple attack. Nat. Chem. Biol. 5, 317, 2009.

23. HOLOPAINEN J.K., GERSHENZON J. Multiple stress factors and the emission of plant VOCs. Trends Plant Sci. 15, 176, 2010.

24. VICKERS C.E., GERSHENZON J., LERDAU M.T., Loreto F. A unified mechanism of action for volatile isoprenoids in plant abiotic stress. Nat. Chem. Biol. 5, 283, 2009. 
25. WITZGALL P., PROFFIT M., ROZPEDOWSKA E., BECHER P.G., ANDREADIS S., CORACINI M., LINDBLOM T.U.T., REAM L.J., HAGMAN A., BENGTSSON M. et al. "This is not an Apple" - Yeast Mutualism in Codling Moth. J. Chem. Ecol. 38, 949, 2012.

26. DUDAREVA N., PICHERSKY E. Metabolic engineering of plant volatiles. Curr. Opin. Biotech. 19, 181, 2008.

27. LAOTHAWORNKITKUL J., PAUL N.D., VICKERS C.E., POSSELL M., TAYLOR J.E., MULLINEAUX P.M., HEWITT C.N. Isoprene emissions influence herbivore feeding decisions. Plant Cell Environ. 31, 1410, 2008.

28. UNSICKER S.B., KUNERT G., GERSHENZON J. Protective perfumes: the role of vegetative volatiles in plant defense against herbivores. Curr. Opin. Plant Biol. 12, 479, 2009.

29. MUMM R., POSTHUMUS M.A., DICKE M. Significance of terpenoids in induced indirect plant defence against herbivorous arthropods. Plant Cell Environ. 31, 575, 2008.

30. BENGTSSON J.M., GONZALEZ F., CATTANEO A.M., MONTAGNÉ N., WALKER W B., BENGTSSON M., ANFORA G., IGNELL R., JACQUIN-JOLY E., WITZGALL P. A predicted sex pheromone receptor of codling moth Cydia pomonella detects the plant volatile pear ester. Front. Ecol. Evol. 2 (33), 1, 2014.

31. GONZALEZ F., BENGTSSON J.M., WALKER W.B., RODRIGUES SOUSA M.F., CATTANEO A.M., MONTAGNÉ N., DE FOUCHIER A., ANFORA G., JACQUIN-JOLY E., WITZGALL P. et al. A conserved odorant receptor detects the same 1-indanone analogs in a tortricid and a noctuid moth. Front. Ecol. Evol. 3 (131), 1, 2015.

32. RODRIGUEZ-SAONA C.R., RODRIGUEZ-SAONA L.E., FROST C.J. Herbivore-induced volatiles in the perennial shrub, Vaccinium corymbosum, and their role in inter-branch signaling. J. Chem. Ecol. 35, 163, 2009.

33. DELANEY K.J., WAWRZYNIAK M., LEMAŃCZYK G., WRZESIŃSKA D., PIESIK D. Synthetic Cis-jasmone exposure induces wheat and barley volatiles that repel the pest cereal leaf beetle, Oulema melanopus L. J. Chem. Ecol. 39, 620, 2013.
34. PIESIK D., WENDA-PIESIK A., KOTWICA K., ŁYSZCZARZ A., DELANEY K.J. Gastrophysa polygoni herbivory on Rumex confertus: Single leaf VOC induction and dose dependent herbivore attraction/repellence to individual compounds. J. Plant Physiol. 168, 2134, 2011a.

35. GERMINARA G.S., CONTE A., LECCE L., DI PALMA A., DEL NOBILE M.A. Propionic acid in bio-based packaging to prevent Sitophilus granarius (L.) (Coleoptera, Dryophthoridae) infestation in cereal products. Innov. Food Sci. Emerg. 11, 498, 2010.

36. PIESIK D., WENDA-PIESIK A., WEAVER D.K., MORRILL W. L. Influence of Fusarium crown rot disease on semiochemical production by wheat plants. J. Phytopathol. 155, 488, 2007.

37. PIESIK D., WEAVER D.K., RUNYON J.B., BUTELER M.L., PECK G.E., MORRILL W.L. Behavioral responses of wheat stem sawflies to wheat volatiles. Agric. For. Entomol. 10, 245, 2008.

38. PIESIK D., ROCHAT D., VAN DER PERS J., MARIONPOLL F. Pulsed odors from maize or spinach elicit orientation in European corn borer neonate larvae. J. Chem. Ecol. 35, $1032,2009$.

39. ZOUBIRI S., BAALIOUAMER A. GC and GC/MS analyses of the Algerian Lantana camara leaf essential oil: Effect against Sitophilus granarius adults. J. Saudi Chem. Soc. 16, 291, 2012.

40. ZIAEE M., MOHARRAMIPOUR S., FRANCIKOWSKI J. The synergistic effects of Carum copticum essential oil on diatomaceous earth against Sitophilus granarius and Tribolium confusum. J. Asia-Pacific Entomol. 17, 817, 2014.

41. PIESIK D., LEMAŃCZYK G., SKOCZEKA., LAMPARSKI R., BOCIANOWSKI J., KOTWICA K., DELANEY K.J. Fusarium infection in maize: Volatile induction of infected and neighboring uninfected plants has the potential to attract a pest cereal leaf beetle, Oulema melanopus. J. Plant Physiol. 168, 1534, 2011b. 